\title{
CDM Regulations 2015 Explained
}


Downloaded by [] on [26/04/23]. Copyright @ ICE Publishing, all rights reserved. 


\section{CDM Regulations 2015 Explained}

Raymond Joyce BSc, MSc, LLB, CEng, FICE

Freeths LLP, UK 
Published by ICE Publishing, One Great George Street, Westminster, London SW1P 3AA.

Full details of ICE Publishing sales representatives and distributors can be found at:

www.icevirtuallibrary.com/info/printbooksales

\section{Other titles by ICE Publishing:}

Practical Guide to Using the CDM Regulations 2015.

Tony Putsman and Paul McArthur. ISBN 978-0-7277-5990-0

CDM 2015 Questions and Answers. Pat Perry. ISBN 978-0-7277-6032-6

ICE Manual of Health and Safety in Construction, 2nd edition.

Ciaran McAleenan and David Oloke (eds.). ISBN 978-0-7277-6010-4

The CDM Regulations Explained, published in 1995.

ISBN 978-0-7277-2034-4

The CDM Regulations Explained, 2nd edition, published in 2001.

ISBN 978-0-7277-3036-7

CDM Regulations 2007 Explained, published in 2007.

ISBN 978-0-7277-3496-9

This edition, CDM Regulations 2015 Explained, published in 2015

www.icevirtuallibrary.com

A catalogue record for this book is available from the British Library

ISBN 978-0-7277-6009-8

(C) Thomas Telford Limited 2015

ICE Publishing is a division of Thomas Telford Ltd, a wholly-owned subsidiary of the Institution of Civil Engineers (ICE).

All rights, including translation, reserved. Except as permitted by the Copyright, Designs and Patents Act 1988, no part of this publication may be reproduced, stored in a retrieval system or transmitted in any form or by any means, electronic, mechanical, photocopying or otherwise, without the prior written permission of the Publisher, ICE Publishing, One Great George Street, Westminster, London SW1P 3AA.

This book is published on the understanding that the author is solely responsible for the statements made and opinions expressed in it and that its publication does not necessarily imply that such statements and/ or opinions are or reflect the views or opinions of the publishers. Whilst every effort has been made to ensure that the statements made and the opinions expressed in this publication provide a safe and accurate guide, no liability or responsibility can be accepted in this respect by the author or publishers.

Whilst every reasonable effort has been undertaken by the author and the publisher to acknowledge copyright on material reproduced, if there has been an oversight please contact the publisher and we will endeavour to correct this upon a reprint.

Words importing the masculine gender only shall include the feminine gender and vice versa as applicable.

Contains public sector information published by the Health and Safety Executive and licensed under the terms of the Open Government Licence v1.0, v2.0 and v3.0.

Commissioning Editor: Amber Thomas

Production Editor: Rebecca Taylor

Market Development Executive: Elizabeth Hobson

Typeset by Academic + Technical, Bristol

Index created by Indexing Specialists (UK) Ltd, Hove, East Sussex

Printed and bound by Ashford Colour Press, Gosport 


\section{Contents}

Preface

About the author

Table of cases

Table of UK statutes

Table of statutory instruments

Abbreviations

01

Introduction

Have the CDM Regulations improved the health and safety record?

The origin and evolution of the CDM Regulations

02

Framework of health and safety law

Introduction

Common law

UK legislation

European health and safety initiative

An overview of the Regulations

Introduction

Application of the Regulations

Notification

Duty holders

Construction phase plan

Health and safety file

Revocations and amendments

Periodic review of the Regulations

Published guidance

04

General duties and principles

Introduction

Appointing a contractor

Cooperation

Duty to warn

Prevention

Communication and documentation

05

Provisions for the welfare of workers

Introduction

Duties

Sanitary conveniences

Washing facilities

Drinking water

Changing rooms and lockers 
Facilities for rest 36

$\begin{array}{ll}\text { First aid } & 37\end{array}$

Concluding remarks $\quad 37$

06

Consideration for hazardous operations

Introduction

Duties relating to health and safety on construction sites

Safe places of construction work

Site movement

Site environment

49

Construction of structures

52

Specific hazards

07

Suitable, sufficient and competent

Introduction

65

The test of suitability and competence

65

Competence for individuals

08

The client

Introduction

69

Client types

70

Agreement between clients

General duties

75

Duty to make appointments

79

09

The principal designer

85

Introduction

85

Definition

86

Appointment of the principal designer

Who can be the principal designer?

88

Duties of the principal designer

10

The designer

101

Who is a designer?

101

What is design?

101

Selecting a designer

The client as designer

105

A contractor as designer

105

Duties of designers

105

Designs prepared or modified outside of Great Britain 
Definition

Selecting a principal contractor

Duties of the principal contractor

Consultation and engagement with workers

Powers of the principal contractor

The construction phase plan

Definition

Background

The duty to prepare and monitor the construction phase plan

The client's involvement in the construction phase plan

Content within a construction phase plan

Checklist of matters for inclusion in a construction phase plan

\section{The health and safety file}

Definition

What information should be included in a health and safety file?

Who takes responsibility for the health and safety file?

What happens to the health and safety file on completion of the construction work?

\section{Contract documentation}

Introduction

Clients and agreement

The professional appointments - duty of care

Terms of engagement of the principal designer

Terms of engagement of designers

Contractors' tender documentation 
Criminal proceedings

$17 \ldots \ldots \ldots \ldots \ldots \ldots \ldots \ldots$ Transitional and saving provisions

Introduction

Projects with no existing CDM coordinator or principal contractor

Projects with an existing CDM coordinator

\section{Bibliography}

Appendix $1 \ldots \ldots \ldots \ldots \ldots$. The 'have you done' checklists

Appendix 2

Construction (Design and Management) Regulations 2015

Appendix $3 \ldots \ldots \ldots \ldots \ldots$. Temporary or Mobile Construction Sites Directive

Appendix 4

Pre-construction information 
We in the construction industry have lived with the Construction (Design and Management) Regulations - commonly referred to as the CDM Regulations for over 20 years and, as if to avoid complacency, a new version of the Regulations came into force on 6 April 2015.

The changes in the 2015 Regulations are the result of a hard pruning that has reduced the word count, put more responsibility on the client, changed the arrangements for domestic work and introduced a new role, referred to as the principal designer. This book is therefore entirely different from my earlier books on the 1994 and 2007 Regulations.

The changes ensure that the CDM Regulations remain centre stage for legislation that affects the construction industry. In their third version, it is questionable whether the latest revision to the Regulations represents a triumph of European jurisdiction over UK sovereignty, the lobbying of business interests of those within the construction industry and its clients, or a straightforward response to continue to improve the health and safety record of the construction industry, or all three!

The CDM Regulations represent the latest initiative to improve the health and safety record of the construction industry by influencing the design, management and construction processes. For most readers of this book, it will be important to them to have an authoritative explanation of the Regulations and insight as to how they are likely to affect their own professional and business interests. The Regulations establish principles to improve health and safety management and avoid an easy prescriptive approach, which requires designers and clients to exercise judgement. The onus on designers to avoid hazards or mitigate risks to health and safety should stimulate innovative design solutions. I am in no doubt that the Regulations will continue to be a controversial source of debate and a subject of lobbying, partly encouraged by the Secretary of 
State's obligation to carry out a review of the Regulations every 5 years. In the meantime, the 2015 Regulations present many challenges, which I hope will be faced and overcome with the help of this book. The new Regulations also coincide with the digital revolution in the construction industry that makes possible the Building Information Modelling (BIM) initiative. The application of the Regulations will be made easier by BIM, to the benefit of designdriven improvements in health and safety management.

I owe a debt of gratitude to many colleagues and clients, too many to mention, who have ensured that the CDM Regulations have never been far from my work as a construction solicitor. My gratitude to Yvonne, my wife, represents the largest debt because it is she who has lived through the CDM story and this latest chapter with patience and good humour! 


\section{About the author}

Raymond Joyce BSc, MSc, LLB, CEng, FICE has over 35 years' experience in the construction industry as a chartered civil engineer and a solicitor. $\mathrm{He}$ is also an accredited adjudicator and mediator. His first book on the 1994 CDM Regulations established his reputation as an authority on construction health and safety in addition to his reputation for assisting his clients safely through the maze of construction law.

Raymond is a member of the ICE Legal Affairs Panel and Chairman of the Dispute Resolution Panel and has been a member of several British Standards committees and a European Working Group. 
Downloaded by [] on [26/04/23]. Copyright @ ICE Publishing, all rights reserved. 
Brazier v. Skipton Rock Co. Ltd [1962] 1 All

ER $955 \ldots \ldots \ldots \ldots \ldots$. . . . . . . . . 67

Edwards v. National Coal Board [1949] All

ER $743($ CA) . . . . . . . . . . . . . . 8

Gibson v. Skibs A/S Marina [1966] 2 All ER

$476 \ldots$

Independent Broadcasting Authority v. EMI

Electronics Ltd and BICC Construction Ltd

(1980) 14 BLR 1 HL . . . . . . . . . . . . . . . . 108

Maloney v. A. Cameron Ltd [1961] 2 All

ER $934 \ldots \ldots \ldots \ldots \ldots$. . . . . . . . . 67

R. v. F. Howe and Son (Engineers) Limited [1999] 2 All ER 249 . . . . . . . . . . . . . 167

R. v. Friskies Petcare Limited $[10 / 3 / 2000]$ unreported . . . . . . . . . . . . . . 167

TE Eckersley and Others v. Binnie \& Partners and Others [1988] CILL 388 . . . . . . . . . 23

Wilsons and Clyde Coal Co. Ltd v. English [1938] AC 57 . . . . . . . . . . . . . . . . 169 
Downloaded by [] on [26/04/23]. Copyright @ ICE Publishing, all rights reserved. 


\section{Table of} UK statutes
Civil Evidence Act 1968 c. 64 . . . . . . . . . . 168 Company Directors Disqualification Act 1986

c. $46 \ldots \ldots \ldots \ldots$. . . . . . . . . . . . 167, 168

Company (Rights of Third Parties) Act 1999

c. $31 \ldots \ldots \ldots \ldots \ldots$. . . . . . . . . . . 159

Corporate Manslaughter and Corporate

Homicide Act 2007 c. 19 . . . . . . . . . . . . 10, 163

Employment Rights Act 1996 c. 18 . . . . . . . 127

Energy Act 2004 c. $20 \ldots \ldots \ldots \ldots$. . . . 14, 19

Enterprise and Regulatory Reform Act 2013

c. 24 . . . . . . . . . . . . . . . . . . . . . . . 169

European Communities Act 1972 c. 68 .... . . 11

European Communities (Amendment) Act 1986

c. $58 \ldots \ldots \ldots \ldots \ldots \ldots \ldots \ldots$. . . . . . . . . 11

Factories Act 1961 c. 34 . . . . . . . . . . . . 3

Fire (Scotland) Act 2005 asp 5 . . . . . . . 166

Health and Safety at Work etc. Act 1974 c. 37

... 9-10, 22, 40, 72, 109, 121, 164-5, 166, 168, 170

Health and Safety Offences Act 2008 c. 20 . . 166

Housing Grants, Construction and Regeneration

Act 1996 c. 53 . . . . . . . . . . . . . 161

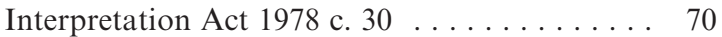

Occupiers Liability Act 1957 c. 31 . . . . . . 140

Occupiers Liability Act 1984 c. 3 . . . . . . . 140

Territorial Sea Act 1987 c. 49 . . . . . . . . . . 14 
Downloaded by [] on [26/04/23]. Copyright @ ICE Publishing, all rights reserved. 


\section{Table of statutory instruments}

Dock Regulations 1934/279 . . . . . . . . . 67

Building (Safety, Health and Welfare)

Regulations 1948/1145 . . . . . . . . . . . . . 67

Quarries Order 1956/1780 . . . . . . . . . . . 67

Construction (Working Places) Regulations

1966/94 . . . . . . . . . . . . . . . . . . . . 67

Safety Representatives and Safety Committees

Regulations $1977 / 500$. . . . . . . . . . . . . . 127

Electricity at Work Regulations 1989/635 . . . 66, 67

Health and Safety (Display Screen Equipment)

Regulations 1992/2792 . . . . . . . . . . . . . 12

Manual Handling Operations Regulations 1992/

2793 . . . . . . . . . . . . . . . . . . . . . . . . 12

Personal Protective Equipment at Work

Regulations 1992/2966 . . . . . . . . . . . . . . 12

Workplace (Health, Safety and Welfare)

Regulations 1992/3004 ......... 12, 19, 110

Health and Safety (Enforcing Authority)

Regulations 1998/494 . . . . . . . . . . . . . . 19, 164

Provision and Use of Work Equipment

Regulations 1998/2306 . . . . . . . . . . . 12, 170

Management of Health and Safety at Work

Regulations 1999/3242 .... 10-11, 12, 26-7, 66, 67, $77,106,118,121,136-8,139,170$

Health and Safety (Miscellaneous Amendments)

Regulations 2002/2174 . . . . . . . . . . . . . 12

Regulatory Reform (Fire Safety) Order 2005/1541 . . . . . . . . . . . . . 165, 166

Health and Safety (Enforcing Authority for

Railways and Other Guided Transport Systems)

Regulations 2006/557 . . . . . . . . . . . . . 18

Control of Asbestos Regulations 2012/632 . . . 153

Health and Safety at Work etc. Act 1979

(Application outside Great Britain) Order 2013/

$240 \ldots \ldots \ldots \ldots \ldots \ldots \ldots$. . . . . . . . . . . . . . . 
Reporting of Injuries, Diseases and Dangerous

Occurrences Regulations 2013/1471 _... 126, 151

Health and Safety (Consultation with

Employees) Regulations 2013/1471 . . . . . . . 127

Enterprise and Regulatory Reform Act 2013 (Health and Safety) (Consequential Amendments) Order

2013/1666 . . . . . . . . . . . . . . . 169 


\section{Abbreviations}

1994 Regulations

Construction (Design and Management) Regulations 1994

2007 Regulations Construction (Design and

Management) Regulations 2007

2015 Regulations Construction (Design and Management) Regulations 2015

ACOP Approved Code of Practice

ALARP as low as reasonably practicable

BIM Building Information Modelling

CDM Regulations

Construction (Design and Management) Regulations

Commission Health and Safety Commission

EU European Union

Executive Health and Safety Executive

Framework Council Directive of 12 June 1989 Directive on the introduction of measures to encourage improvements in the safety and health of workers at work (89/391/EEC)

Management

Management of Health and

Regulations

Safety at Work Regulations 1999

HASWA 1974

Health and Safety at Work etc. Act 1974

SFAIRP so far as is reasonably practicable

SPV

TMCSD special-purpose vehicle

Temporary or Mobile Construction Sites Directive. The Council Directive of 25 June 1992 on the implementation of minimum safety and health requirements at temporary or mobile construction sites (92/57/EEC) 